Lepr Rev (1993) 64, 267-269

\title{
Human immunodeficiency virus and leprosy- type 1 reactions, nerve damage and steroid therapy: 'a case report'
}

\author{
R. BWIRE \& H. J. S. KAWUMA \\ St Francis Leprosy Centre, Buluba, PO Box 1059 Jinja, Uganda
}

Accepted for publication 11 March 1993

\begin{abstract}
Summary In this study a 28-year-old female with both BL leprosy and HIV infections is discussed. Her clinical progress was followed until she completed MDT. During this period she developed recurrent reactional episodes, nerve damage and intercurrent illnesses-some of which might have been due to steroids.
\end{abstract}

\section{Introduction}

There is very little information on the interaction between the human immunodeficiency virus (HIV) and leprosy, especially concerning the clinical progress of leprosy. A report from Zambia has described some clinical observations on 10 leprosy patients suffering from HIV. ${ }^{1}$ This paper describes the clinical progress of a BL patient who received and completed the WHO recommended MDT regimen.

\section{CASE REPORT}

M.J., a 28-year-old Ugandan female market vendor, presented at a leprosy clinic we were holding with a 3-month history of multiple skin lesions.

Examination revealed her to be in good general condition, with skin lesions clinically compatible with borderline lepromatous (BL) leprosy. The posterior tibial and radial cutaneous nerves showed thickening bilaterally and were non-tender. There was no evidence of peripheral neuropathy. On slit skin smear, the highest bacteriological index (BI) was 2 (left ear lobe).

She agreed to take part in an ongoing study that required screening for HIV antibodies. After we had counselled the patient, an HIV test was done, and she tested positive on both the HIV check (Dupont) and Wellcozyme HIV Recombinant test.

The patient was put on Dapsone $100 \mathrm{mg}$ once daily, Clofazimine $50 \mathrm{mg}$ once daily and Rifampicin $600 \mathrm{mg}$ with Clofazimine $300 \mathrm{mg}$ once monthly (supervised).

She presented with a type 1 reaction 4 months after onset of MDT with swelling of the skin lesions on the trunk and upper limbs, with no nerve tenderness or peripheral neuropathy. She was hospitalized and put on prednisolone $40 \mathrm{mg}$ once daily which cured 
the skin irregularities. This treatment was maintained for 2 weeks and for the following 6 weeks she was weaned off steroids. The highest BI during this episode was 1 (left ear lobe). The patient was subsequently discharged in good general condition.

She was re-admitted 2 months after discharge suffering from a type 1 reaction having had swelling of the facial lesions for 1 week. On examination, she had a weakness of the left obicularis oculi muscle and a bilateral weakness in abducting the little finger. There was no nerve tenderness, but she had developed diarrhoea a few days after her discharge which had persisted up to the time of her re-admission. Further examination revealed oral candidiasis, with genital and axillary sores. Her general condition had deteriorated. Prednisolone $40 \mathrm{mg}$ once daily was recommenced, and the facial swellings then subsided. After 4 weeks of this treatment there was no improvement in the weakness of her little fingers or the left arbicularis oculi. Then she developed a bilateral weakness in opposition of the thumb. Steroids were slowly tapered off. The BI during this episode was 0 . The patient received the proper treatment for her other disorders, and clinically improved. She was discharged and continued with MDT from her local clinic. She has since been in and out of hospital with a recurrence of genital sores, oral candidiasis and fevers. The patient has completed 24 doses of MDT and the BI has remained negative. She is currently under surveillance.

\section{Discussion}

After earlier reports by Lamfers, suggesting a possible association between HIV and leprosy, ${ }^{2}$ it has not been uncommon to have to treat patients suffering from both conditions. In one major study, Ponnighaus et al. ${ }^{3}$ have demonstrated that HIV infection is probably not a risk factor for clinical leprosy per se. However, the information on clinical progress in patients who are also HIV infected is still minimal. A multibacillary patient whose lesions subsided quickly under anti-leprosy therapy has been described by Kennedy et al. $^{4}$

In this case, response to chemotherapy (MDT) per se appears satisfactory, with a decline of the BI from 2 to 0 after $7 \frac{1}{2}$ months.

Perhaps the relapse of the Type 1 reaction in this patient was caused by the inadequate course of steroids which only lasted for 6 weeks. However, the possibility of recurrent reactional episodes of type 1 among these patients with an increased incidence of nerve damage compared to non HIV patients has to be borne in mind.

It is possible that the steroid therapy given during the first episodes of reversal reaction speeded the onset of oral and genital candidiasis with which the patient presented on readmission. However, steroids should probably be given in symptomless HIV positive patients if this is indicated by the clinical manifestations.

The fact that the steroid treatment only had a disappointing response in the patient's functional nerve recovery might also be due to the inadequate prednisolone course. On the other hand, this could just as likely be due to a necrotizing vasculitis in the peripheral nerves by the neurotrophic HIV. ${ }^{5}$

This is the first multibacillary leprosy patient in Uganda who completed the WHO recommended MDT regimen and is HIV positive, albeit with an on/off intermittent illness. 


\title{
Acknowledgments
}

The follow up of this patient has been made possible by the financial support from the UNDP/World Bank/WHO Special Programme for Research and Training in Tropical Diseases (TDR).

\section{References}

1 Vreeburg AEM. Clinical observations on leprosy patients with HIV infection in Zambia. Lepr Rev, 1992; 63: $134-40$

2 Lamfers EJP, Bastiaans AH, Mravunac M, Rampen FHJ. Leprosy in the acquired immunodeficiency syndrome. Ann Intern Med, 1987; 107: 111-12.

${ }^{3}$ Ponninghaus JM, Mwanjasi LJ, Fine PEM, Shaw M, Turner AC, Oxborrow SM, Lucas SB, Jenkins PA, Sterne JAC, Bliss L. Is HIV infection a risk factor for leprosy? Int J Lepr, 1991; 59: 221-3.

${ }^{4}$ Kennedy C, Chin A Lien RAM, Stolz E, van Joost T, Naafs B. Leprosy and human immunodeficiency virus infection; a closer look at the lesions. Int J. Derm, 1990; 29: 139-40.

${ }^{5}$ Patki AH. Some possible interactions of M. leprae and HIV in the peripheral nerves. Int J Lepr, 1991; 59: 3312.

Lepr Rev (1993) 64, 267-269

\section{Virus de l'immunodéficience humaine et lèpre—réactions du type I, atteintes du nerf et thérapeutique aux stéroïdes: rapport d'un cas.}

\section{R. BWIRE ET H. J. S. KaWUMA}

Résumé Dans cette étude, nous discutons le cas d'une femme agée de 28 ans atteinte à la fois de lèpre BL et d'infection par HIV. Son évolution clinique est suivie jusqu'à la fin du traitement MDT. Au cours de cette période, elle a présenté des poussées réactionnelles recurrentes, une atteinte du nerf et des maladies intercurrentes dont certaines pourraient être dûes aux stéroïdes.

\section{El virus de la inmunodeficiencia humana y la lepra-Reacciones de Tipo 1, Daños de los nervios y la terapia de esteroides: Estudio de un caso}

\author{
R. BWIRE Y H. J. S. KAWUMA
}

Resumen Se discute el caso de una mujer de 28 años con infecciones de lepra y VIH. Se ha seguido su progreso clínico hasta completar MDT. Durante este período, desarrolló reacciones recurrentes, daños de los nervios y enfermedades intercurrentes, algunas de las cuales podrían ser debidas a los esteroides. 